\title{
KRAŠKA POLJA V SLOVENIJI
}

Izvirni znanstveni članek

COBISS 1.01

DOI: $10.4312 /$ dela.53.23-43

\section{Izvleček}

Kraška polja so kotanje v krasu, ki so zelo pogoste zlasti na Dinarskem krasu. Kljub številnim skupnim značilnostim se pojavljajo $\mathrm{v}$ zelo različnih kraških okoljih in delujejo na različne načine. $\mathrm{V}$ raziskavi je predstavljena nova tipizacija kraških polj, ki poenostavlja dosedanje tipizacije. Polja opredeljuje glede na geomorfološko okolje, v katerem se pojavljajo, kot ojezerjena, prelivna, pritočna in predledeniška. $\mathrm{V}$ raziskavi smo na osnovi nove tipizacije opredelili vseh 35 kraških polj v Sloveniji.

Ključne besede: geomorfologija, kras, kraško polje, tipizacija, Slovenija

\section{KARST POLJES IN SLOVENIA}

\section{Abstract}

Poljes are very common karst depressions especially in the Dinaric Karst. Despite their many common characteristics, they occur in very different karst environments and function in various ways. The research presents a new typification of poljes, which simplifies the previous ones. It defines the poljes according to the geomorphological environment in which they occur as inundated, overflow, inflow and pre-glacial poljes. In the research, we defined all 35 karst poljes in Slovenia on the basis of the new typification.

Keywords: geomorphology, karst, polje, typification, Slovenia

* Oddelek za geografijo, Filozofska fakulteta Univerze v Ljubljani, Aškerčeva 2, SI-1000 Ljubljana, Slovenija e-pošta: uros.stepisnik@ff.uni-lj.si 


\section{UVOD}

Kraška polja so največje kraške kotanje. Prve objave o kraških poljih iz 19. stoletja jih opisujejo kot kraške kotanje brez površinskega odtoka, za katere se je uporabljal nemški termin die Wanne (slov. kad) (Gams, 1978). Šele ob koncu 19. stoletja se v mednarodni literaturi za njih prične uporabljati termin polje, ki izhaja iz slovanskih jezikov (Mojsisovicz, 1880). V tem času so nastale tudi prve definicije kraških polj, ki so jih opredeljevale kot velike kraške kotanje z uravnanim dnom in kraškim odtokom. Daljša os njihovih dnov naj bi bila orientirana v smeri lokalne geološke strukture in prekrita s terciarnimi sedimenti. Morfogenezo polj so takrat interpretirali kot zadnjo fazo razvoja kraških kotanj, kjer vrtače prerastejo v uvale, uvale pa v kraška polja (Cvijić, 1895; Cvijić, 1900).

Sodobne interpretacije kraških polj (Gams, 1974; Gams, 1978; Gams, 2003; Ford, Williams, 2007) so predhodnim precej podobne in jih opredeljujejo kot kotanje, ki imajo značilna obsežna in relativno uravnana dna, ki jih sklenjeno vzdolž celotnega roba obdajajo višja pobočja. Dna polj navadno prekrivajo fluvialne ali jezerske naplavine. Za kraška polja je značilna površinska hidrologija v obliki vodotokov in občasnega ojezerjevanja, izjemoma so ojezerjena tudi stalno. V vseh kraških poljih deluje kraška hidrologija, kar pomeni, da je odtok iz polj podzemni - skozi kraški vodonosnik (Gams, 1978). V primeru, da površinska hidrologija v dneh polj več ne deluje, jih opredeljujemo kot suha ali reliktna kraška polja. V primeru, da voda iz teh kraških kotanj odteka površinsko, jih ne moremo opredeljevati s terminom kraška polja, ampak kvečjemu kot kraške kotline (Stepišnik, 2020). Dimenzije polj so v literaturi različno opredeljene (Cvijić, 1895; Cvijić, 1900; Gams, 1978; White, 1988; Ford, Williams, 2007). Cvijić (1895), ki je prvi kraška polja opredelil po morfometričnih kriterijih, je za kriterij minimalne širine njihovih dnov določil vsaj en kilometer. Gams (1978) je v definiciji kraških polj, ki je danes sprejeta tudi v mednarodni literaturi (Jennings, 1985; White, 1988; Ford, Williams, 2007), opredelil minimalni kriterij širine 400 metrov. V kasnejših publikacijah je morfometrični kriterij najmanjše širine polj znižal na 400 metrov, saj se je v praksi izkazalo, da veliko število manjših kraških polj v Sloveniji ne presega širine pol kilometra (Gams, 2003). Te dimenzije jasno razlikujejo polja od ostalih kraških kotanj manjših dimenzij, ne glede na njihov nastanek ali hidrološko delovanje. Površine kraških polj lahko obsegajo do 405 kvadratnih kilometrov, kot jih meri največje Livanjsko polje v Hercegovini.

Tipizacij kraških polj je veliko. Tipizacijo polj, ki se danes uporablja tudi v mednarodni literaturi (Bögli, 1980; Jennings, 1985; Jennings, 1997; Nicod, 2003; Bonacci, 2004; Gunn, 2004; Williams, 2004), je podal Gams (1978), ki je tipiziral polja glede na njihove morfogenetske in hidrološke značilnosti. Njegova tipizacija je bolj ali manj dosledno sprejeta tudi v mednarodni krasoslovni literaturi (Jennings, 1985; White, 1988; Ford, Williams, 2007; Sauro, 2012). Glede na njihovo hidrološko funkcijo, torej na način pritekanja in odtekanja vode, je kraška polja razdelil na pritočno-ponorniška, prelivna, 
izvirno-ponorniška polja zajezenega krasa, raztočno-ponorniška in suha polja. Pritočno-ponorniška polja imajo površinske pritoke iz nekraških območij, ki na kraškem polju poniknejo. Prelivna polja imenuje tudi izvirno-ponorniška in imajo kraške izvire na eni in ponore na drugi strani ter neprepustne ali slabo prepustne kamnine na dnu polja. Izvirno-ponorniška polja zajezenega krasa imenuje tudi polja v epifreatični coni. Ta imajo dno v bližini gladine podzemne vode, tako da so dna polj ob višjih vodostajih poplavljena. Raztočno-ponorniška polja $\mathrm{v}$ dneh gradijo neprepustne ali slabo prepustne kamnine; tako se vode iz njih raztekajo na robne kraške kamnine in v njih ponikajo. Suha polja je opredelil kot polja brez stalnih ali občasnih vodnih tokov. Le ob izrednih dogodkih so dna polj še vedno lahko hidrološko aktivna (Gams, 1978).

Po nastanku oziroma morfogenetskih značilnostih je Gams (1978) razlikoval robna, periferna in pretočna polja, polja $v$ gladini podzemne vode in piedmontska gorska polja. Robna polja so nastala na stiku vododržnih in kraških kamnin. Površinske vode $\mathrm{v}$ dnu polja odlagajo material $\mathrm{z}$ nekraškega območja $\mathrm{v}$ obliki vršaja, nato pa ponirajo $\mathrm{v}$ dnu ali na robu polj. Dna perifernih polj gradijo neprepustne kamnine, zato se vodotoki iz njih raztekajo na robove, kjer ponirajo v kras. Ta polja so pravzaprav bolj ali manj enotna uravnava povezanih slepih dolin. Pretočna polja so nastala na močnejših prelomnih conah. Tektonsko deformirane kamnine delujejo kot bariere podzemnim vodam. Ta območja vodotoki prečkajo površinsko, zato se na površju oblikujejo uravnana dna kraških polj. Polja $v$ višini piezometričnega nivoja so večje sklenjene površine, ki so se uravnale predvsem z robno korozijo, ker je del površja segal v nivo poplavnih vod. Gladina podzemne vode na območju polj je morala biti stabilna daljše obdobje, da je imela bočna korozija na voljo dovolj časa za oblikovanje uravnave. Nastanek piedmontskih gorskih polj je podoben robnim poljem, le da so uravnave v teh kotanjah oblikovali prodonosni vodotoki iz poledenelih ali periglacialnih območij. Prod se je v dneh polj odložil v obliki vršaja, hkrati pa je na pobočja kotanj delovala bočna korozija nenasičene snežnice (Gams, 1978).

Gamsova (1978) klasifikacija kraških polj implicira povezavo med morfogenetskimi značilnostmi in recentno hidrološko funkcijo. Skoraj pri vseh tipih polj se tako hidrološka funkcija polj navezuje na morfogenetske značilnosti: robna polja hidrološko delujejo kot pritočno-ponorniška, pretočna polja kot prelivna, polja v gladini podzemne vode kot izvirno ponorniška polja zajezenega krasa in periferna polja kot raztočno-ponorniška polja. Hidrološka funkcija se tako navezuje na procese nastanka polj in obratno. Le piedmontskemu gorskemu tipu polj Gams (1978) ne opredeli hidrološke funkcije.

Gamsova tipizacija kraških polj (Gams, 1978) je v rabi že skoraj 50 let. Poleg tega, da deli polja na osnovi dveh kriterijev, ki se med seboj skoraj popolnoma prekrivata, in je kot taka nekoliko eklektična, tudi interpretacija njihovega nastanka ni popolnoma skladna s sodobnim mofrogenetskim in morfodinamičnim razumevanjem krasa. Kot taka je le v omejenem obsegu uporabna v praksi, kar ima za posledico pogosto nedoslednost interpretacije kraških polj v poljudni in strokovni literaturi. Kljub temu, 
da so določeni tipi polj vezani na zelo specifične procese na kraškem površju ali $\mathrm{v}$ podzemlju, ki so vezani le na določena geomorfološka okolja, jih ta tipizacija ne predvideva oziroma ne upošteva (Gams, 1978).

Slika 1: Cerkniško polje ob visokem vodostaju (foto: U. Stepišnik, 2020).

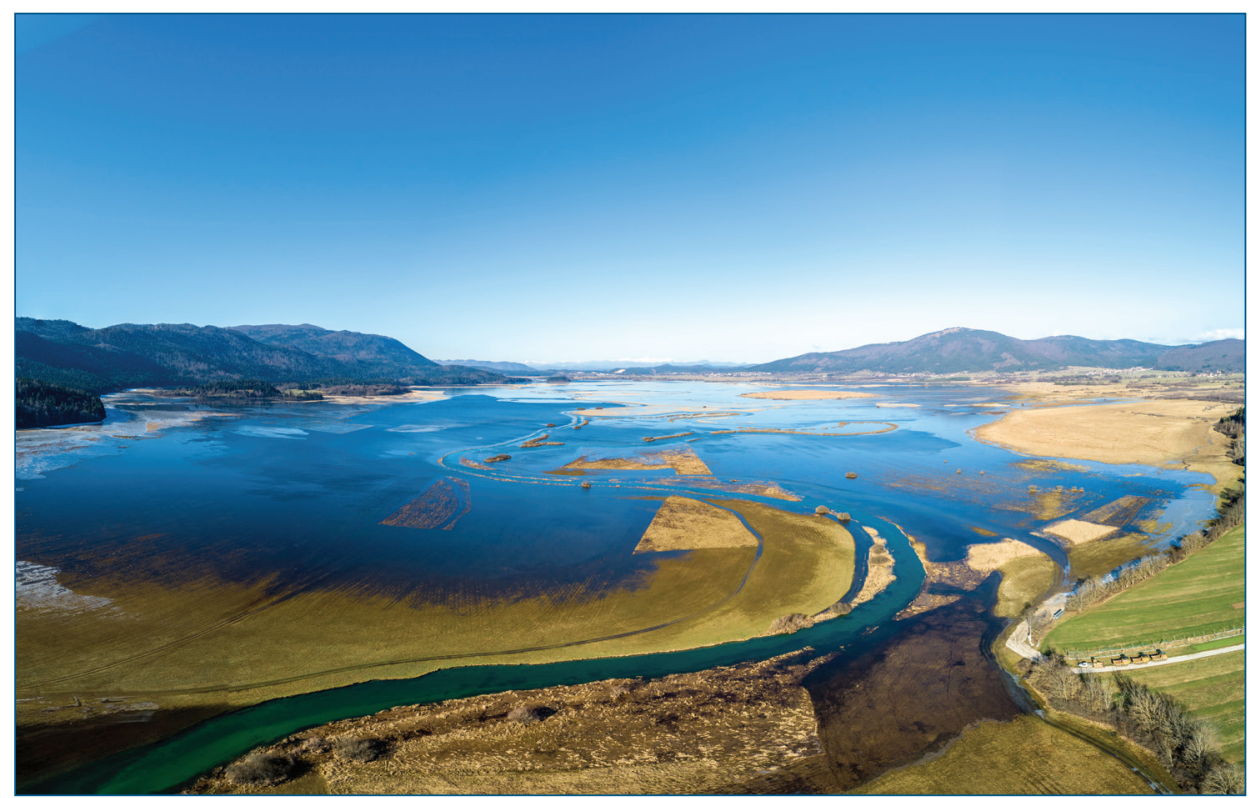

Namen članka je podati novo tipizacijo kraških polj, ki ne sledi izključno klasični morfogenetski in hidrološki interpretaciji (Cvijić, 1900; Gams, 1963; Gams, 1978; Ford, Williams, 2007), ampak temelji na moderni morfodinamični interpretaciji tipov krasa, v katerih so polja oblikovana. Cilji članka so (a) podati morfodinamično delitev specifičnih kraških okolij, kjer se pojavljajo kraška polja, (b) izdelati novo sistematično tipizacijo kraških polj glede na podano morfodinamično tipizacijo kraških okolij, v katerih so polja oblikovana, in (c) na osnovi nove tipizacije sistematizirati kraška polja Slovenije.

\section{MORFODINAMIČNA TIPIZACIJA KRAŠKIH POLJ}

Tipe krasa lahko opredelimo na osnovi prevladujočih geomorfoloških procesov na površju, kar opredeljujemo kot morfodinamično tipizacijo krasa. Morfodinamična oziroma geomorfodinamična tipizacija izhaja iz geomorfološkega analitskega pristopa (Pavlopoulos, Evelpidou, Vassilopoulos, 2009), ki temelji na interpretaciji površinskih oblik na osnovi analize recentnih geomorfnih procesov in njihove dinamike. 
Najosnovnejše in hkrati tudi najbolj tipično delovanje krasa je vezano na tri osnovne procese: vertikalni odtok padavinskih vod, kemično denudacijo, ki je prevladujoč proces odnašanja kamninske mase na površju in v podzemlju, ter zanemarljivo akumulacijo raztopljenega materiala (Šušteršič, 1986). V primeru, da je gladina podzemne vode v krasu dovolj globoko, da niti ob visokih vodah ne seže na površje, imenujemo tovrstno kraško okolje globoki kras. Za tovrstno morfodinamiko kraškega okolja so značilne različne geomorfne oblike, ki so $\mathrm{v}$ tlorisu ovalnih oblik kot najrazličnejše kraške kotanje in kopaste vzpetine. V tovrstnih kraških okoljih ni kraških polj, četudi delujejo najbolj tipično kraško (Stepišnik, 2020). Kljub temu v okolju globokega krasa najdemo kraška polja, ki so nastala $\mathrm{v}$ drugačnih morfodinamičnih kraških okoljih. Tovrstna polja lahko v reliefu identificiramo kot obsežne kraške kotanje z uravnanim dnom. Ta niso hidrološko aktivna oziroma lahko površinska hidrologija v njih omejeno deluje le ob izjemnih vremenskih dogodkih. Njihova dna so navadno razčlenjena $\mathrm{z}$ vrtačami in brez naplavin oziroma se te pojavljajo le $\mathrm{v}$ posameznih zaplatah. $\mathrm{V}$ živoskalnih dneh so ponekod ohranjene tudi struge nekdanjih vodotokov. Zaradi odsotnosti procesov, ki so v preteklosti taka polja oblikovali, jih imenujemo reliktna polja.

\subsection{Polja plitvega krasa}

S plitvim krasom označujemo geomorfna okolja, v katerih dna kraških kotanj segajo do gladine podzemne vode. $Z$ vidika hidrogeološke dinamike je plitvi kras vezan na majhno globino vadozne cone, oziroma je ta na območjih globljih kraških kotanj povsem odsotna. V okoljih plitvega krasa torej delujejo vsi tipični kraški procesi razen vertikalnega odtekanja padavinske vode na območjih globljih kotanj. Dna teh kotanj so neposredno v epifreatični oziroma freatični coni, zato so občasno ali stalno ojezerjena.

Okolja plitvega krasa so prisotna na območjih, kjer je kraški vodonosnik iz strani zajezen tako, da je gladina podzemne vode v bližini površja. Na to vpliva predvsem topografska lega nekraških kamnin ali sedimentnih bazenov na iztočnih straneh kraških vodonosnikov. Na gladino podzemne vode vpliva tudi gladina morja. Območja plitvega krasa so pogosta v reliefnih znižanjih vzdolž tektonsko deformiranih con, ki jih imenujemo podolja. Nastanejo zaradi zniževanja površja ob tektonskih ekstenzijah ali zaradi pospešene dinamike denudacije vzdolž tektonsko deformiranih con. V podoljih je, poleg nižje topografske lege, zaradi tektonsko deformirane kamnine, ki deluje kot slabo prepustna bariera, kraški vodonosnik lokalno zajezen, zato so vzdolž podolij pogosta območja plitvega krasa. V kraških kotanjah plitvega krasa ne delujejo vsi tipični kraški procesi, saj je vertikalni odtok padavinskih vod onemogočen, s tem pa tudi kemična denudacija, ki bi zniževala površje v vertikalni smeri. Navadno se iz kraških vod odlaga netopen oziroma slabo topen drobnozrnat sediment, ki dna prekrije z naplavino.

Najpreprostejše hidrološko delovanje je značilno za kraška polja, ki jih literatura po načinu nastanka opredeljuje kot polja $\mathrm{v}$ piezometrični gladini oziroma po hidrološki funkciji kot izvirno-ponorniška polja zajezenega krasa (Gams, 1978; Gams, 2003). To so 
kraške kotanje ustreznih dimenzij, ki segajo do gladine podzemne vode, zato so občasno ali stalno ojezerjene. Poimenovanje tega tipa polj, ki ga je uvedel Gams (1978), ni najprimernejše, saj je piezometer naprava za merjenje tlaka v tekočinah, ki se uporablja za določevanje gladine podzemne vode. V nadaljevanju bomo za ta tip polj dosledno uporabljali ustreznejši termin ojezerjena kraška polja, ki opisuje njihove morfodinamične značilnosti.

Ta polja so lahko stalno ali občasno ojezerjena. Dna stalno ojezerjenih kraških polj segajo do freatične cone kraškega vodonosnika. Ta tip polj je v Dinarskem krasu vezan predvsem na bližino morske obale, kjer je zaradi holocenskega dviga morske gladine in posledičnega dviga gladine podzemne vode $\mathrm{v}$ okoliškem krasu trajno poplavilo večje kraške kotanje. Tako je najrazličnejšim tipom večjih kraških kotanj ojezerilo dna, zato jih zaradi sedanjih hidroloških značilnosti tipiziramo kot stalno ojezerjena kraška polja. V Sloveniji teh polj ni, zato na tem mestu navajamo nekaj tovrstnih primerov, ki so locirani na Dinarskem krasu vzdolž Jadranske obale, kjer se jih zaradi stalne ojezerjenosti označuje s hidronimi, kot so Doberdobsko jezero na Krasu, Vransko jezero v Dalmaciji ali Vransko jezero na Cresu.

Bolj pogosta so občasno ojezerjena kraška polja. To so kraške kotanje ustreznih dimenzij, katerih dna segajo v epifreatično cono in so občasno poplavljena. Območja kotanj teh polj ne ležijo na območjih večjega hidravličnega gradienta, ki bi povzročil, da se vode preko dnov polj pretakajo od izvirnih $\mathrm{k}$ ponornim delom. V dna občasno ojezerjenih kraških polj priteka voda pretežno iz estavel, v katere ob spustu gladine tudi odteče. Kljub temu, da nekatere kotanje nimajo dvojne hidrološke funkcije, temveč ločeno delujejo kot izviri ter ponikve, večjih površinskih tokov med izvirnimi in ponornimi območji v poljih tega tipa načeloma ni.

Slika 2: Kotanja Petelinjskega jezera je tipično občasno ojezerjeno kraško polje (foto: U. Stepišnik, 2020).

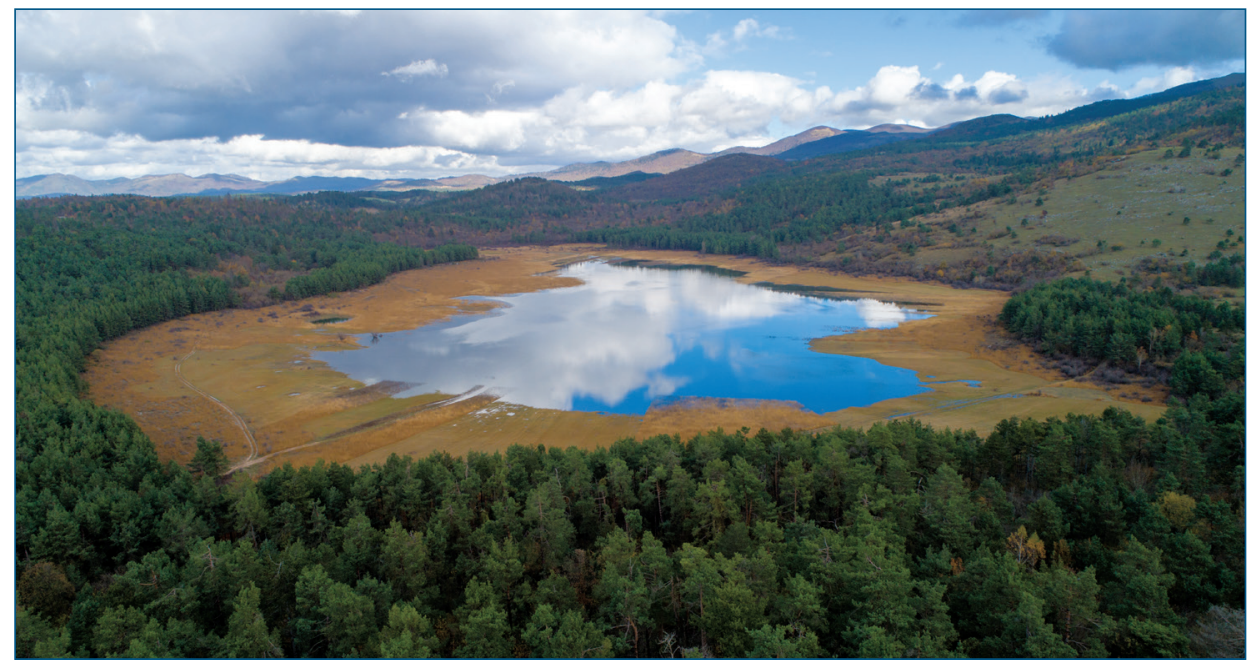


Drug tip polj plitvega krasa imenujemo prelivna kraška polja, ki podobno kot občasno ojezerjena polja segajo v epifreatično hidrogeološko kraško cono. Razlikujejo se $\mathrm{v}$ tem, da imajo prelivna kraška polja $\mathrm{v}$ dneh površinski vodotok oziroma reko, ki prevaja vodo od izvirnega proti ponornemu delu polja. Prav zato jih je pretekla literatura tipizirala kot izvirno-ponorniška polja oziroma prelivna polja (Gams, 1978; Gams, 2003). Ta tip polj je prostorsko vezan na tektonsko deformirana območja ali območja tektonskih ekstenzij, vzdolž katerih so nastali znižani deli reliefa oziroma podolja. Hidrološko bariero na območju polja lahko tvorijo tudi nekraške kamnine. Če je hidravlični gradient prečen na cono hidrološke bariere, ob kateri je oblikovano polje, se površinske vode preko njega prelivajo od izvirnega $\mathrm{k}$ ponornim delom. Ob visokih gladinah podzemnih vod pa so dna teh polj občasno ojezerjena. Prelivna kraška polja veljajo za najbolj tipična kraška polja predvsem zaradi jasno izraženih obodov in pestrosti kraških oblik, ki se v njih pojavljajo. Na pritočni strani vodotoki najpogosteje izvirajo v izvirnih zatrepih in zatrepnih dolinah, reke pa preko polj zaradi drobnozrnatih sedimentov in majhnega hidravličnega gradienta navadno meandrirajo. Za odtočne dele teh kraških polj so značilne ponikve in ponori, ki se navadno nahajajo pod strmimi pobočji. Med zelo tipične primere prelivnega polja uvrščamo tudi največje kraško polje na svetu, Livanjsko polje.

Slika 3: Planinsko polje je eno od največjih prelivnih kraških polj v Sloveniji (foto: U. Stepišnik, 2020).

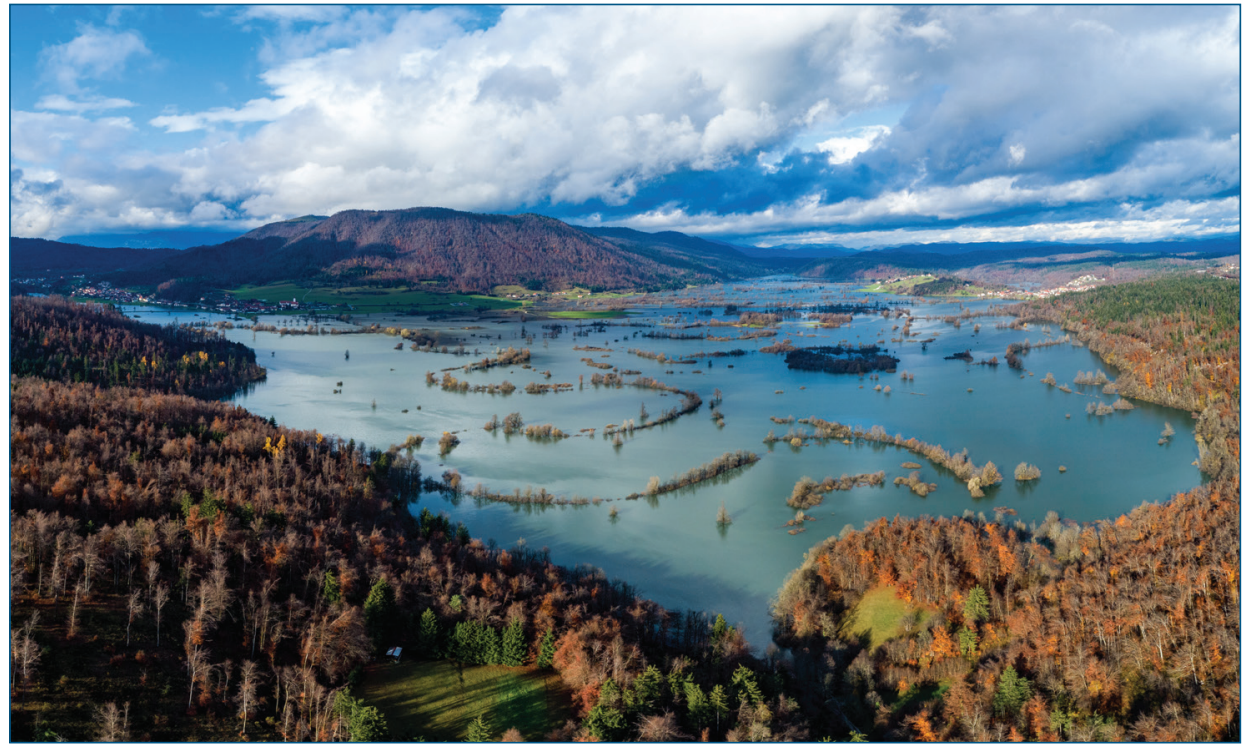




\subsection{Fluviokraška polja}

Morfodinamično kraško okolje, kjer je zaradi intenzivnega mehanskega preperevanja matične kamnine in debelejše plasti preperine zavrt vertikalni odtok padavinskih vod, označujemo s terminom fluviokras. Zaradi zavrtega odtekanja padavinskih vod skozi preperino $\mathrm{v}$ kras pride do oblikovanja lokalnih površinskih vodotokov, ki preoblikujejo površje. Pojavljanje fluviokraških okolij je litološko pogojeno, saj je odvisno predvsem od odpornosti kamnine na mehansko preperevanje. Najpogosteje je fluviokras vezan na zakrasele kamnine, ki na površju intenzivno mehansko preperevajo. To so običajno tankoplastoviti apnenci, lapornati apnenci in dolomiti (Roglić, 1958). Tudi površje na tektonsko deformiranih kamninah pogosto deluje fluviokraško (Gostinčar, 2016; Stepišnik, 2020).

Na uravnanih površjih padavinske vode kljub preperini vertikalno odtekajo v kraški vodonosnik, torej delujejo vsi kraški procesi nemoteno. Ta okolja načeloma nimajo golih skalnih površin, saj jih v celoti pokriva preperina, zato jih imenujemo pokriti kras (Gams, Kunaver, Radinja, 1973). Na pobočjih pokritega krasa padavinska voda odteka v obliki površinskih vodotokov. Ti erodirajo preperino ter oblikujejo linearne vdolbine vzdolž pobočij oziroma t. i. erozijske jarke. Ob njihovem izteku se na uravnanih površjih odlaga naplavina v obliki vršajev. Površinski tokovi ob izteku vršajev skozi naplavino v ponikvah odtekajo v podzemlje.

Večje kotanje, ki jih zapolnjujejo naplavine s fluviokraških pobočij, opredeljujemo kot kraška polja. Tip polj, ki je značilen za ta kraška okolja, literatura po hidrološki funkciji opredeljuje kot pritočno-ponorniška polja, po nastanku pa kot robna polja (Gams, 1978; Gams, 2003). To poimenovanje ni najustreznejše, saj je za kraška polja bistveno, da vode $\mathrm{z}$ njih odtekajo v podzemlje. Poleg tega je poimenovanje robno polje zamenljivo tudi s perifernim poljem, saj imata beseda rob in periferija podoben pomen. Ker ta polja opredeljuje površinski pritok voda iz fluviokraških okolij, ta polja imenujemo pritočna kraška polja. Podobno kot pri ostalih kraških poljih to poimenovanje prav tako implicira njihovo osnovno morfodinamiko.

Ta tip polj naj bi bil značilen za stik nekraških in kraških kamnin, a je iz primerov navedenih v literaturi razvidno, da vode nanje vedno pritekajo iz fluviokraških območij in nikoli iz nekarbonatnih okolij, na primer iz flišnih kamnin (Gams, 1978; Gams, 2003). Tudi največje zaprte kotanje na stiku nezakraselih flišnih kamnin in kraških območij, kot je na primer Vremska dolina pri Divači ali slepa dolina Temenice pri Ponikvah, vedno opredeljujemo kot slepe doline in ne kot kraška polja, kljub temu da izpolnjujejo vse morfografske in hidrološke kriterije kraških polj (Gams, 1978; Gams, 2003). Torej je dosedanja opredelitev pritočnih kraških polj preveč ohlapna (Gams, Kunaver, Radinja, 1973; Gams, 1978); opredeliti jih moramo kot polja na stiku fluviokraških in kraških okolij, kjer vode površinsko pritekajo na polja in na polju odtekajo v kraški vodonosnik.

Manjša pritočna kraška polja delujejo enostavno, saj se nanje stekajo le vode iz erozijskih jarkov na pobočjih polj. Navadno je v njihovi okolici več erozijskih jarkov 
in dolkov, od koder so površinske vode v dna polj nasule naplavino v obliki vršajev. Skupine vršajev tako tvorijo uravnavo v dnu kraškega polja. Na površju so navadno sledovi nekdanjih ali občasnih rečnih strug, ki se iztečejo v ponikvah. Na ponornih delih polj so pogoste tudi sufozijske vrtače (Gostinčar, 2011). Ker ta polja ležijo nad gladino podzemne vode v krasu, so suha; le ob intenzivnejših vremenskih dogodkih nanje pritekajo vodotoki. Navadno so tako majhna, da njihove dimenzije bistveno ne presegajo morfometričnih kriterijev za kraška polja.

Slika 4: Strmica je eno od manjših pritočnih kraških polj. Leži ob vznožju erozijskih jarkov pod Hrušico (foto: U. Stepišnik, 2020).

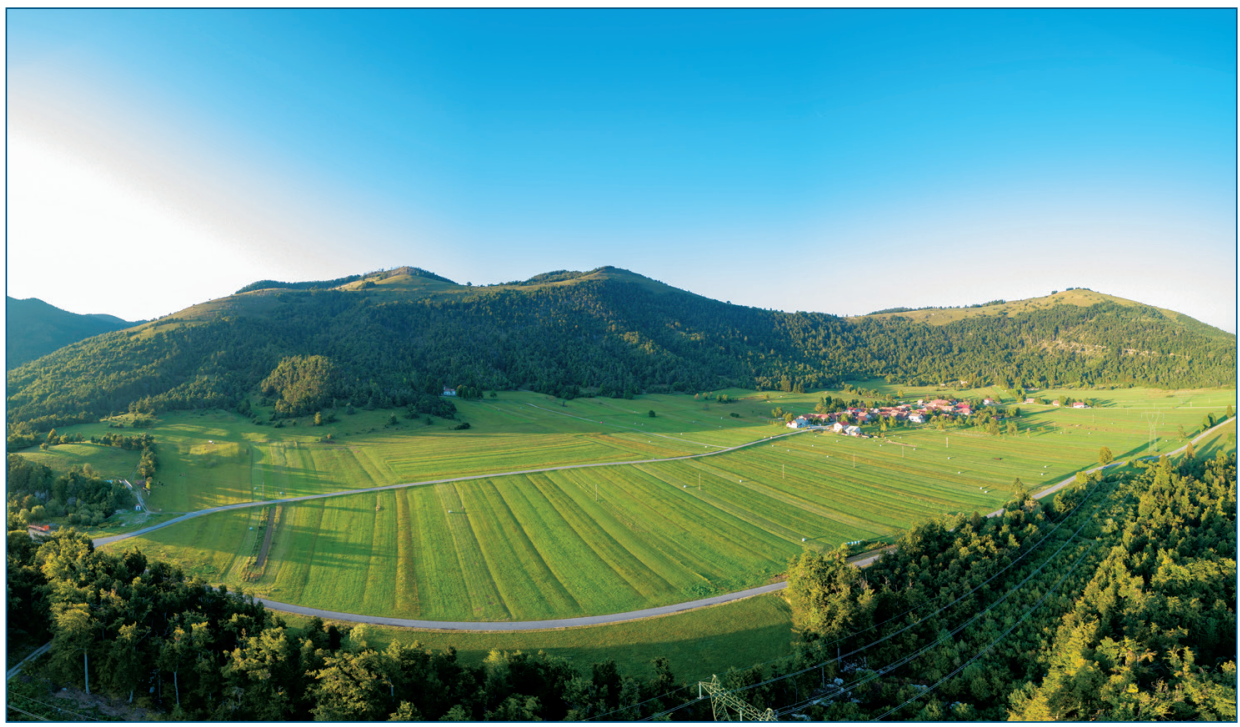

Večja pritočna polja so morfološko in hidrološko bolj kompleksna. Površinski tokovi, ki imajo porečje v fluviokraškem zaledju, pritekajo na ta kraška polja in odtekajo $\mathrm{v}$ podzemlje. To niso razpršeni manjši občasni vodotoki kot v primeru enostavnih robnih polj, pač pa v dolinah nanje pritekajo večji, pogosto stalni vodotoki. Ob visokih vodostajih so najnižji deli polj ob odtočnem delu tudi ojezerjeni. Ta polja dosegajo veliko večje dimenzije, saj lahko njihove širine dosegajo tudi nekaj kilometrov.

\subsection{Glaciokraška polja}

Kraška območja, ki so bila v preteklosti poledenela, imenujemo ledeniški kras oziroma pogosteje s tujko glaciokras (Smart, 2004). Glaciokras je rezultat delovanja poledenitve na kraški geomorfni sistem (Kunaver, 1983; Smart, 2004; Ford, Williams, 2007; Žebre, Stepišnik, Kodelja, 2013; Adamson, Woodward, Hughes, 2014; Žebre, 
Stepišnik, 2014a; Žebre, Stepišnik, 2014b; Žebre, Stepišnik, 2015). Ledeniško površje se morfološko jasno loči na dva dela - na erozijsko in akumulacijsko območje. V zgornjem delu ledenikov prevladuje akumulacija ledu in posledično intenzivna ledeniška erozija, tj. trganje in brušenje matične kamnine, medtem ko $\mathrm{v}$ spodnjem delu prevladujeta ablacija oziroma taljenje ledu in akumulacija ledeniškega materiala.

Kljub temu, da je večina vodotokov pod ledeniki odtekala v kraški vodonosnik, se je del teh vod, zlasti v ablacijskem delu, kjer so bile izdatne količine ledenikih akumulacij, stekal pod ledeniki in ni vtekal v kras. Ledeniške akumulacije so delovale kot neprepustna podlaga, ki je preprečevala odtok vod v kraški vodonosnik. Zato so površinske vode, kot predledeniški tokovi, iztekale iz čela ledenika. Ti tokovi so preko kraškega površja odlagali fluvioglacialni material v obliki vršajev. Vodni tokovi so skozi fluvioglacialne nanose ob izteku vršajev odtekali v kraški vodonosnik. V primerih, ko je bilo površje pred ledeniki dovolj strmo, vode niso odlagale materiala, temveč so $\mathrm{v}$ pobočja abrazijsko vrezala globoke in strme, ozkim soteskam podobne rečne struge, ki jih imenujemo korita. Predledeniški vršaji so se v teh primerih odložili preko bolj uravnanih kraških območij v nižjih topografskih legah pod koriti.

$\mathrm{V}$ primeru, da predledeniški vršaji zapolnjujejo večje kraške kotanje $\mathrm{z}$ ustreznimi dimenzijami, jih imenujemo predledeniška kraška polja. V večini primerov so to suha kraška polja, saj se je pritekanje vodnih tokov na ta polja ob koncu pleistocena z umiki ledenikov končalo. Na poljih so pogosto ohranjene rečne struge nekdanjih predledeniških tokov (Stepišnik, 2015). Ta polja v celoti ležijo v vadozni coni krasa, zato navadno nimajo recentne hidrološke funkcije. Občasne ojezeritve nižjih delov teh polj so rezultat izdatnih padavin, tudi lokalnih pritokov, ki zaradi slabo prepustnih predledeniških nanosov ne morejo sproti odtekati v podzemlje, zato voda zastaja na površju.

Starejša literatura ta polja opredeljuje kot piedmontska polja (Gams, 1978) (it: piede di monte = vznožje gore) oziroma piedmontska gorska polja (Gams, 1978; Gams, 2003), kar ni najprimernejši termin, saj ne ležijo pod gorami, ampak navadno v visokogorju, pred iztoki nekdanjih ledenikov. Tipični primeri tovrstnih kraških polj so v goratih delih Dinarskega krasa, ki ležijo v bližini nekdanjih poledenitev, kot so Krasno polje na Velebitu (Stepišnik, 2015) ter Grahovo, Dragaljsko, Njegoško in Cetinjsko polje v Črni Gori (Adamson, Woodward, Hughes, 2014; Žebre, Stepišnik, 2014a; Žebre, Stepišnik, 2014b; Žebre, Stepišnik, 2015).

\subsection{Polja kontaktnega krasa}

Termin kontaktni kras opredeljuje geomorfna okolja, ki ležijo na aktivnem hidrološkem stiku med fluvialnim in kraškim geomorfnim sistemom. Glede na hidrološko pozicijo ločimo dva osnovna tipa kontaktnega krasa: ponorni in izvirni kontaktni kras (Mihevc, 1991). Ponorni kontaktni kras je okolje, kjer vode iz nekraškega fluvialnega geomorfnega sistema vtekajo v kraškega. Drugi tip kontaktnega krasa je izvirni 
Slika 5: Velo polje pod Triglavom je eno najmanjših kraških poli Slovenije. Uvrščamo ga v predledeniški tip poli (foto: U. Stepišnik, 2020).

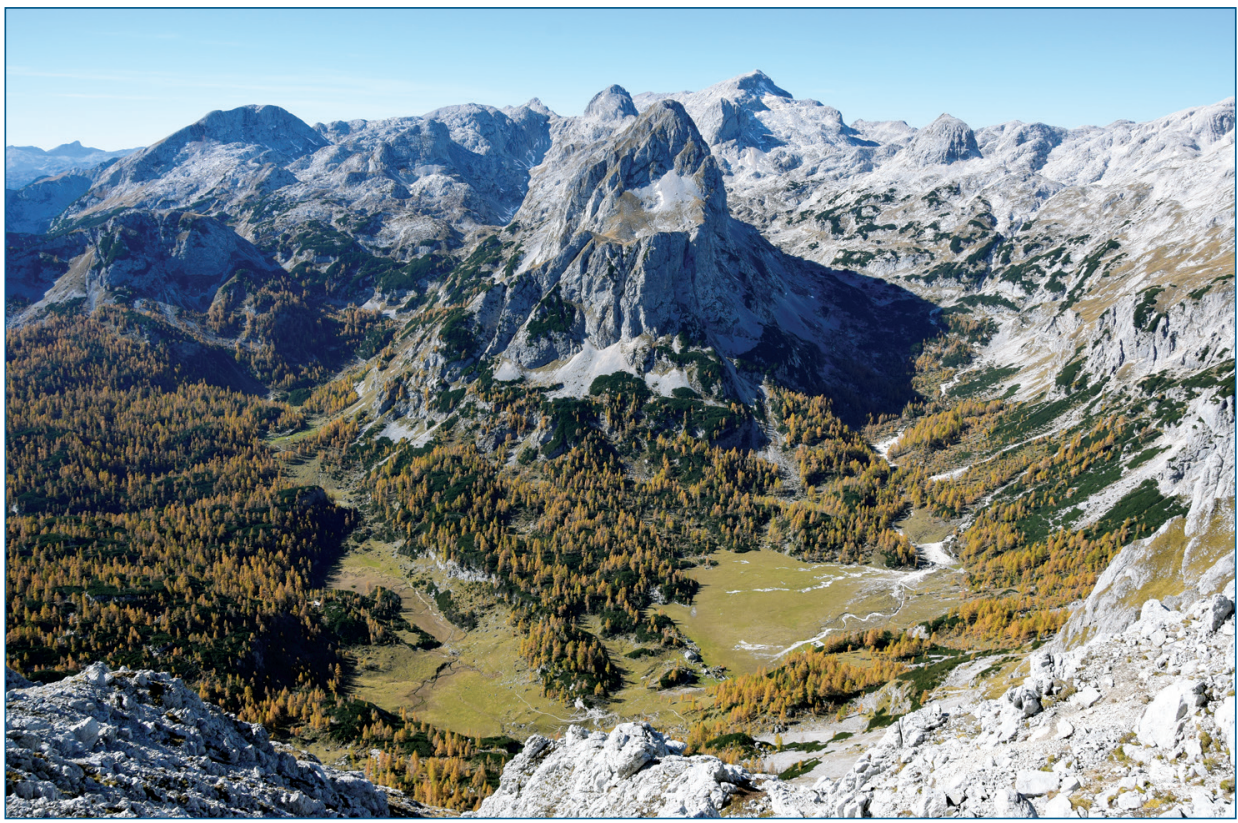

kontaktni kras, ki se oblikuje na območjih iztekanja vode iz kraškega vodonosnika na površje, v fluvialni geomorfni sistem. Na ponornem kontaktnem krasu alogeni tokovi iz nezakraselih kamnin, kjer deluje fluvialni geomorfni sistem, tečejo na kras. Poleg velikih količin vode s seboj prenašajo tudi izdatne količine sedimenta, ki se delno akumulira ob kontaktu, delno pa se nadaljuje s transportom v kraški vodonosnik. Na površju ob kontaktu se oblikujejo značilne geomorfne oblike, kot so vršaji kontaktnega krasa, ponorne doline, ponorni zatrepi in slepe doline.

Kot največjo reliefno obliko, vezano na ponorni kontaktni kras, je Gams (1978) opredelil poseben tip kraških polj. Po njihovi hidrološki funkciji jih je opredelil kot raztočno-ponorniška kraška polja. Za njih naj bi bilo značilno, da imajo v dnu večjo debelino neprepustnih sedimentov, od koder se vode centrifugalno raztekajo proti robu, kjer na stiku z zakraselimi kamninami odtekajo v podzemlje. Na tem stiku naj bi bile slepe doline in njim podobne kotanje (Gams, 1978). Po nastanku je tovrstna polja opredelil tudi kot periferna-obrobna polja (Gams, 2003). Ta polja naj bi sestavljala povezana dna slepih dolin. Kot primere tovrstnih polj navaja Postojnsko, Kočevsko, Kupreško in Glamočko polje.

Ni popolnoma jasno, zakaj je ta tip kraških polj zašel v krasoslovno literaturo. Takšnih sklenjenih območij nezakraselih kamnin ne smemo opredeljevati kot kraška polja. Kraška polja so namreč po osnovni definiciji reliefne kotanje v krasu, ki imajo 
sklenjen obod višji od dna. Uravnano dno mora imeti širino vsaj pol kilometra, uravnava pa mora biti vezana na recentne ali pretekle površinske hidrološke procese. Vode iz kraških polj morajo odtekati v kras. Postojnsko polje, kot najbolj tipični primer raztočno-ponorniškega oziroma periferno-obrobnega polja (Gams, 1978; Gams, 2003), nima teh lastnosti. Deli osrednjega dela polja so višji od oboda, dno ni ravno, pač pa je povečini razčlenjeno s slemenasto-dolinastim fluvialnim reliefom. Tudi dna slepih dolin na robu Postojnskega polja niso povezana v uravnavo. Postojnske kotline torej ne moremo opredeliti kot kraško polje oziroma jo je celo zmotno imenovati Postojnsko kraško polje. Podobno velja za Kočevsko polje, kot primer kombiniranega prelivnega ter pritočnega kraškega polja. Izjema je le porečje Rudniškega potoka, ki pa pravzaprav sploh ne obsega dela dna Kočevskega polja, temveč leži višje nad njegovim severnim obodom. Povirje ima na zaplati laporjev in peščenjakov miocensko-pliocenske starosti ter odteka na sever v ponorni jamski sistem Željnskih jam. Enako velja tudi za tipičen primer raztočno-ponorniškega polja iz osrednjega dela Dinarskega krasa: Kupreško in Glamočko polje. Kupreško polje je tipično pritočno kraško polje (Stepišnik, 2014), medtem ko je Glamočko polje kombinirano pritočno in prelivno polje.

Če povzamemo: literatura (Gams, 1978; Gams, 2003) kot največje oblike ponornega kontaktnega krasa opredeljuje raztočno-ponorniška polja. Teoretično so ta jasno morfografsko, morfometrično in morfodinamično opredeljena. Kljub številnim navedenim primerom polj tega tipa nobeno ne ustreza definiciji kraškega polja. Potemtakem je raba termina raztočno-ponorniško in tudi periferno-obrobno polje neutemeljena; večje kotanje na ponornem kontaktnem krasu torej niso kraška polja.

\section{KRAŠKA POLJA V SLOVENIJI}

Na osnovi morfodinamične funkcije kraških okolij smo izdelali celostno tipizacijo kraških polj Slovenije. Osnovne morfometrične kriterije smo povzeli po Gamsu (2003), kar pomeni, da so polja vse zaprte kraške kotanje, ki imajo sklenjena pobočja, ki so višja od dnov polj. Dna morajo biti relativno uravnana, njihova širina pa mora dosegati minimalne dimenzije okoli 400 metrov.

Skupno število vseh polj v Sloveniji je 35 . Njihova povprečna površina je $4,5 \mathrm{~km}^{2}$. Največje je Cerkniško polje, ki obsega površino okoli $36,5 \mathrm{~km}^{2}$ in ima širino okoli $5 \mathrm{~km}$, najmanjše polje pa je Velo polje pod Triglavom, ki ima površino $0,07 \mathrm{~km}^{2}$, a ima premer le $340 \mathrm{~m}$. Kljub temu, da to polje zaradi premajhne širine ne dosega minimalnih morfometričnih kriterijev za kraška polja, smo ga vseeno vključili v našo tipizacijo. Razlog je v tem, da to polje predstavlja prvi opisan primer piedmontskega gorskega polja (Gams, 1963). Vsa ostala polja, ki so vključena v tipizacijo, pa dosegajo vse morfometrične kriterije kraških polj (Gams, 2003). 
Slika 6: Tipi kraških polj.

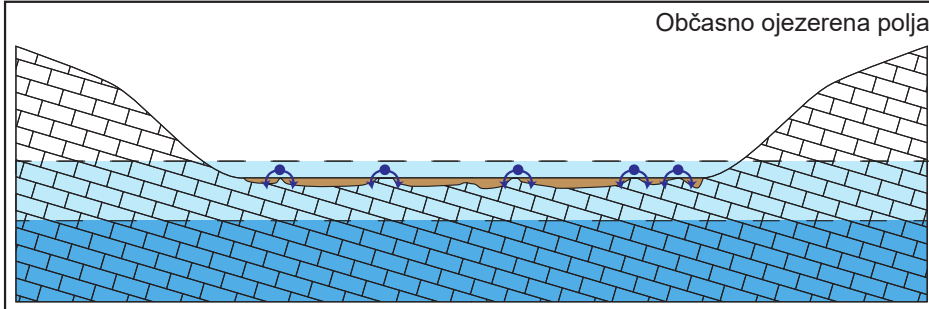

Prelivna polja

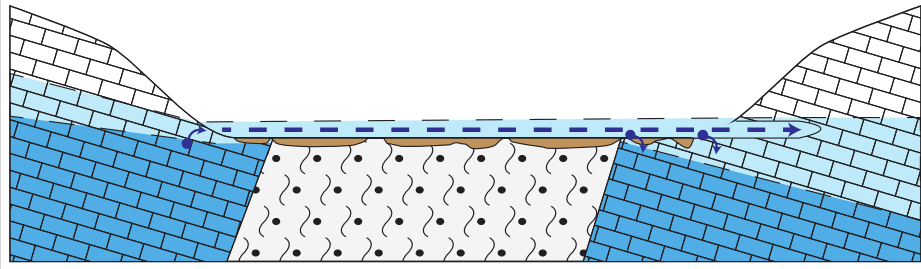

$\dot{i}$
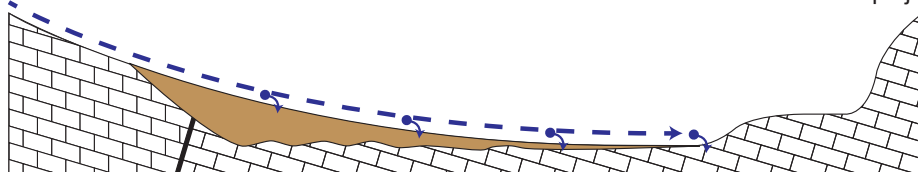
$1 N$ N 1 - 1 -

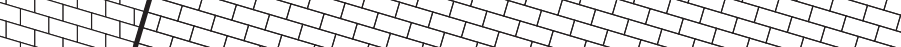

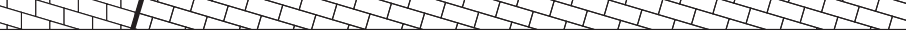

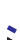

$\therefore-$

Predledeniška polja

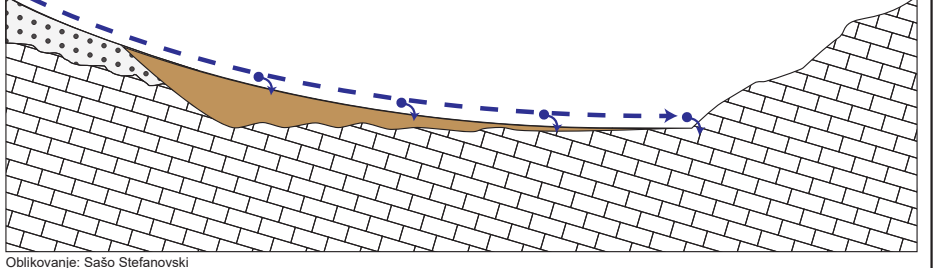

Kras

Fluviokras

¿• ?• Hidrološka bariera

$\because \because \because \vdots$ Ledeniški nanosi

Naplavina

Epifreatična cona

Freatična cona

Ponor

Izvir

q Ponikev

Estavela

- - $\rightarrow$ Površinski tok 
Preglednica 1: Kraška polja v Sloveniji.

\begin{tabular}{|c|c|c|c|}
\hline & Ime & Površina $\left[\mathrm{km}^{2}\right]$ & Tip polja \\
\hline 1 & Cerkniško polje & 36,58 & Občasno ojezerjeno, prelivno, pritočno \\
\hline 2 & Dobrepolje & 10,27 & Občasno ojezerjeno, prelivno, pritočno \\
\hline 3 & Ribniško polje & 21,21 & Prelivno, pritočno \\
\hline 4 & Radensko polje & 8,70 & Prelivno, pritočno \\
\hline 5 & Kočevsko polje & 15,05 & Prelivno, pritočno \\
\hline 6 & Bloško polje & 5,78 & Pritočno \\
\hline 7 & Logaško polje & 4,83 & Pritočno \\
\hline 8 & Koritniško polje & 4,23 & Pritočno \\
\hline 9 & Goteniško polje & 1,79 & Pritočno \\
\hline 10 & Babno polje & 1,62 & Pritočno \\
\hline 11 & Rakitniško polje & 1,14 & Pritočno \\
\hline 12 & Vrbovško polje & 1,05 & Pritočno \\
\hline 13 & Dobsko polje & 0,91 & Pritočno \\
\hline 14 & Hotenjsko polje & 0,76 & Pritočno \\
\hline 15 & Zadlog & 4,23 & Pritočno \\
\hline 16 & Rakovško-unško polje & 1,77 & Pritočno \\
\hline 17 & Črnovrško polje & 1,52 & Pritočno \\
\hline 18 & Žalnsko polje & 0,79 & Pritočno \\
\hline 19 & Koprivniško polje & 0,68 & Pritočno \\
\hline 20 & Strmica & 0,63 & Pritočno \\
\hline 21 & Bločiško polje & 0,32 & Pritočno \\
\hline 22 & Ponikve na Rogu & 0,29 & Pritočno \\
\hline 23 & Loško polje & 14,46 & Prelivno \\
\hline 24 & Lučki dol & 1,42 & Prelivno \\
\hline 25 & Mirnopeško polje & 1,35 & Prelivno \\
\hline 26 & Travnik & 0,83 & Prelivno \\
\hline 27 & Podpeško polje & 0,33 & Prelivno \\
\hline 28 & Ponikve pri Preserjah & 0,20 & Prelivno \\
\hline 29 & Planinsko polje & 9,51 & Prelivno \\
\hline 30 & Globodol & 2,48 & Občasno ojezerjeno \\
\hline 31 & Palško polje & 0,89 & Občasno ojezerjeno \\
\hline 32 & Retje & 0,53 & Občasno ojezerjeno \\
\hline 33 & Petelinjsko polje & 0,43 & Občasno ojezerjeno \\
\hline 34 & Gomance & 2,14 & Predledeniško \\
\hline 35 & Velo polje & 0,07 & Predledeniško \\
\hline
\end{tabular}


Natančne dimenzije kraških polj je v določenih primerih težko natančno opredeliti. Kljub natančnim morfometričnim podatkom o reliefu in terenskim pregledom so robovi nekaterih kraških polj težko določljivi. Robovi namreč pogosto iz uravnanih ali reliefno nekoliko razčlenjenih površij, kjer jih prekriva naplavina, prehajajo v okoliško kraško površje brez izrazitih pregibov. To velja zlasti za kraška polja v fluviokraških okoljih, ki imajo pogosto na odtočnih delih svoje reliktne dele, kjer so nekdanja dna polj že zakrasela in so najpogosteje razčlenjena $\mathrm{z}$ vrtačami. Prav tako je pri tovrstnih poljih in pri tistih v glaciokraških okoljih težko zamejiti pritočne dele, saj dna polj zvezno prehajajo $\mathrm{v}$ rečne doline oziroma na območja ledeniških ali predledeniških nanosov. Prav zato so navedene dimenzije polj, ki jih navajamo v tej raziskavi, v nekaterih primerih nekoliko arbitrarne.

Polja so tipizirana na osnovi morfodinamičnih značilnosti kraških okolij, v katerih so oblikovana; torej po načinu delovanja polj in okoliškega površja. Večina kraških kotanj, $\mathrm{v}$ katerih so oblikovana polja, je oblikovanih pretežno $\mathrm{v}$ homogenem morfodinamičnem okolju, tako da jih uvrščamo v en sam tip. V nekaterih večjih kraških poljih součinkuje več tipov kraških okolij. Zaradi pestrosti delovanja tovrstna polja označujemo kot mešana kraška polja.

Mešano morfodinamično delovanje je značilno za največja polja v Sloveniji. Med najbolj pestra uvrščamo Cerkniško polje in Dobrepolje. Na območju obeh polj je prisotno delovanje, ki je značilno za občasno ojezerjena, prelivna in pritočna polja. Na obeh poljih imamo območja, ki so občasno ojezerjena zaradi dviga nivoja podzemne vode $\mathrm{v}$ krasu. Prav tako so v dneh prisotni površinski vodotoki, ki se pretakajo od izvirnih k ponornim delom, ter površinski vodotoki, ki pritekajo na polja iz fluviokraških območij. Slednji proces je na Dobrepolju prisoten le ob izjemno visokih vodostajih reke Rašice.

Nekoliko manj, a kljub vsemu pestro geomorfološko okolje je značilno tudi za Ribniško, Kočevsko in Radensko polje. Ta polja prav tako tipiziramo kot mešana, saj obsegajo okolja fluviokrasa in plitvega krasa, delujejo pa kot prelivna in kot pritočna polja.

Večina kraških polj ne leži v mešanih geomorfoloških okoljih, tako da je njihova tipizacija preprostejša. Med polja plitvega krasa uvrščamo ojezerjeni in prelivni tip polj. V Sloveniji so ta polja le občasno ojezerjena. Sloveniji najbližje stalno ojezerjeno polje je Doberdobsko polje, ki leži na italijanski strani Krasa. Največje občasno ojezerjeno polje je Globodol. Manjša polja tega tipa so še Retje pri Loškem potoku ter kotanji Petelinjskega in Palškega jezera na Zgornji Pivki. Vsa ta polja ležijo v območju nihanja podzemne vode; občasne ojezeritve se napajajo in odtekajo skozi številne estavele v njihovih dneh.

Prelivna polja delujejo podobno kot občasno ojezerjena polja, le da se ob višjih vodostajih vzdolž polj oblikuje hidravlični gradient, zaradi česar se vode preko dnov pretakajo od izvirnih do ponornih delov. Kljub temu, da ta polja veljajo za najbolj tipična kraška polja (Gams, 1978), njihov delež v Sloveniji obsega le petino - 7 polj. Največje polje tega tipa v Sloveniji je Loško polje, čeprav za najbolj tipičen primer literatura navaja predvsem Planinsko polje (Gams, 2003; Mihevc, 2010). V ta tip polj sodijo tudi Mirnopeško polje in Lučki dol ter manjša polja, kot so Podpeško polje, 
Ponikve pri Preserjah ter Travnik pri Loškem potoku. Dna teh polj so lahko občasno popolnoma ojezerjena, le Loško polje ima ojezerjeno le ponorno območje.

Največ kraških polj v Sloveniji, kar 17, je pritočnega tipa. Navadno so oblikovana na litološkem stiku med dolomiti in apnenci, torej med fluviokraškim in kraškim geomorfnim okoljem. Obseg dnov teh polj je z morfografskega vidika težko določljiv, saj njihova dna zvezno prehajajo $\mathrm{v}$ dna dolin na pritočnih delih polj. Hkrati se tudi njihovi ponorni deli na zaključujejo z reliefno jasno izraženimi pobočji, ampak prehajajo v reliktna dna polj. Reliktni deli predstavljajo živoskalne uravnave, razčlenjene $\mathrm{z}$ vrtačami. Ta prehod je lahko zvezen ali pa izražen $\mathrm{z}$ reliefnim pregibom, ki spominja na živoskalno ježo. Kljub temu, da literatura tovrstne uravnave interpretira kot tektonsko pogojene (Gams, 1973; Gams, 1974), so najverjetneje rezultat zmanjševanja dinamike dotoka fluviokraških naplavin $\mathrm{v}$ dna polj. Robovi polj tako postopoma migrirajo $\mathrm{v}$ smeri pritočnega dela. Vsekakor bodo za potrditev te hipoteze potrebne prihodnje raziskave.

Najpreprostejše oblike pritočnih polj imajo na pritočni strani le erozijske jarke ter dolke, od koder se je fluviokraška naplavina transportirala v dna polj. Dna teh kraških polj tvorijo skupine manjših vršajev. $\mathrm{V}$ dneh, ki so izjemoma ojezerjena le ob izrednih vremenskih dogodkih, so pogoste ponikve. Tovrstna pritočna polja na odtočni strani navadno nimajo reliktnih delov polj. Največje med njimi je Zadloško polje, ostala pa so Rakovško-unško polje, Črnovrško polje, Žalnsko polje, Koprivniško polje, Strmica, Bločiško polje in Ponikve na Rogu.

Druga vrsta pritočnih polj ima bolj kompleksne hidrološke značilnosti, saj se ne napajajo le z lokalnimi vodotoki, ampak nanje pritekajo večji vodotoki iz fluviokraškega zaledja. Večja pritočna polja pa so morfološko in hidrološko bolj kompleksna. Površinski tokovi, ki imajo porečje $\mathrm{v}$ fluviokraškem zaledju, skupaj s sedimenti pritekajo na polja. Vode navadno v nižjih delih polj odtekajo v podzemlje skozi ponikve ali požiralnike. Ob izjemnih vremenskih dogodkih so nižji, odtočni deli polj ojezerjeni. Vsa polja tega tipa se za ponornim delom nadaljujejo v reliktne dele polj, razen Bloškega, Babnega in Rakitniškega polja, ki zaradi strmih pobočij nad ponornimi deli reliktnih uravnav nekdanjih dnov polj nimajo. Poleg omenjenih uvrščamo v ta tip tudi Logaško, Koritniško, Goteniško, Vrbovško, Dobsko in Hotenjsko polje.

Predledeniški polji v Sloveniji sta Velo polje pod Triglavom in Gomance, ki imajo le severni rob na ozemlju Slovenije, večji del polja pa se nahaja na Hrvaškem. Obe sta nastali zaradi nanosov predledeniških tokov v kraške kotanje. Dele Gomanc zapolnjujejo tudi ledeniški nanosi (Žebre in sod., 2016). Obe polji sta suhi, brez recentne hidrološke funkcije. 
Slika 7: Karta kraških polj na slovenskem Dinarskem krasu. Številke kraških polj na karti so enake kot v preglednici 1 (Velo polje - številka 35 - v Julijskih Alpah ni označeno na karti).

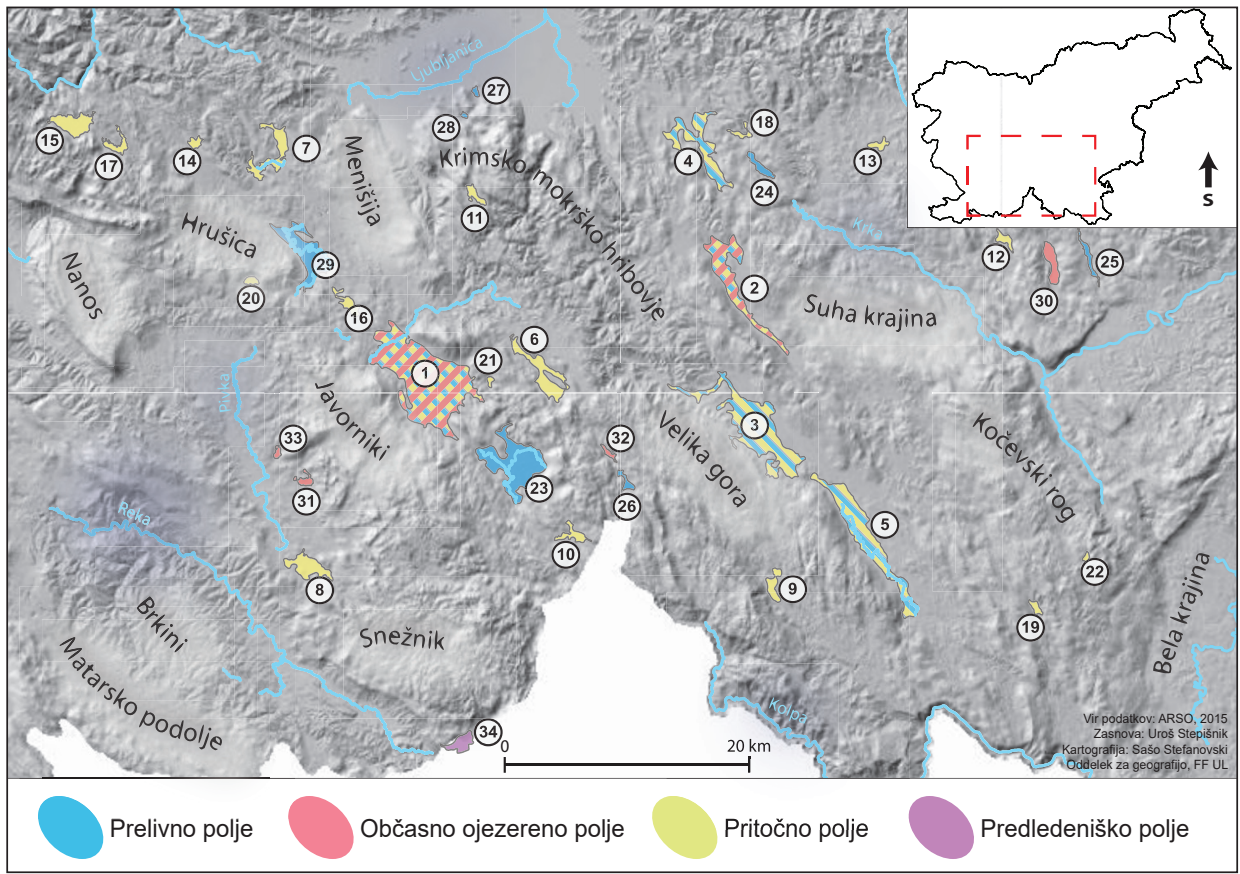

\section{SKLEP}

Nova tipizacija kraških polj, predstavljena v tem članku, povzema dosedanje tipizacije v eno samo. Ta sintetizira vse značilnosti kraških polj, ki so bile do sedaj ločene na posamezne tipizacije, ki so vključevale morfogenetske in hidrodinamične (Gams, 1978; Gams, 2003) značilnosti. Nova tipizacija ne opredeljuje območja polj, ampak jih opredeljuje na osnovi širših geomorfoloških okolij, v katerih se nahajajo. Pri podrobni analizi polj Slovenije se je namreč izkazalo, da so njihove geomorfološke in hidrološke značilnosti odvisne od geomorfoloških značilnosti širše okolice. Nova tipizacija ne vključuje polj kontaktnega krasa, ki jih literatura opredeljuje kot raztočno-ponorniška kraška polja oziroma periferna-obrobna polja (Gams, 1978; Gams, 2003).

V kraških okoljih z nemotenim delovanjem osnovnih kraških procesov, ki jih opredeljujemo s prevladujočim procesom raztapljanja in vertikalnim odtokom raztopine v kraški vodonosnik (Šušteršič, 1986), se kraška polja ne oblikujejo. Pojavljajo se le v okoljih, kjer je delovanje krasa moteno. Motnje, ki pogojujejo nastanek in delovanje polj, so vezane na specifične hidrogeološke značilnosti kraškega vodonosnika ali pa na delovanje površinskih geomorfnih procesov, ki povzročajo mehansko premeščanje mase po kraškem površju. 
Tovrstna tipizacija predvideva tri geomorfna okolja krasa, za katera so značilni štirje tipi kraških polj. Najpreprostejša tipa polj sta vezana na lokalno odsotnost vadozne hidrogeološke cone krasa, kjer je onemogočen vertikalni odtok padavinskih vod, kar hkrati povzroča stalno ali občasno ojezerjenost kraških kotanj; torej na okolja plitvega krasa. V primeru preprostega ojezerjevanja, brez lateralnega pretakanja površinskih vod na območju dnov, govorimo o ojezerjenem tipu polj. Kadar se v dneh polj zaradi hidravličnega gradienta pretakajo oziroma prelivajo vode od izvirnih $\mathrm{k}$ ponornim delom, jih opredeljujemo kot prelivni tip.

Druga dva tipa polj pa sta vezana na mehanski transport materiala po kraškem površju; v obeh primerih gre za fluvialni način transporta. Polja, v katera se odlaga naplavina iz fluviokraških okolij, opredeljujemo kot pritočna polja, polja z naplavino iz glaciokraških okolij pa kot predledeniška.

Z novo tipizacijo smo sistematizirali vsa kraška polja slovenskega krasa. Zaradi različnih vrst kraških okolij smo nekatera uvrstili v več tipov. Tovrstnih polj je 5 in povečini vključujejo največja polja Slovenije. Najbolj raznovrstna sta Cerkniško polje in Dobrepolje, ki ju hkrati uvrščamo med občasno ojezerjena, prelivna in pritočna polja. Ostala polja delujejo pretežno v homogenih kraških okoljih. Največ je pritočnih kraških polj, ki so značilna za aktivne hidrološke stike, kjer vodotoki na kras pritekajo iz fluviokraških območij. Manjši delež polj je značilnih za okolja plitvega krasa, med katerimi prevladujejo prelivna polja. V Sloveniji so najbolj redka glaciokraška polja, kamor zaradi majhnih dimenzij pogojno uvrščamo le Velo polje pod Triglavom. Gomance na Snežniku so prav tako predledeniško polje, a le manjši delež dna sega na slovensko ozemlje.

\section{Literatura in viri}

Adamson, K. R., Woodward, J. C., Hughes, P. D., 2014. Glaciers and rivers: Pleistocene uncoupling in a Mediterranean mountain karst. Quaternary Science Reviews, 94, 0, str. 28-43. DOI: 10.1016/j.quascirev.2014.04.016.

Bögli, A., 1980. Karst hidrology and physical speleology. Berlin, Heidelberg, New York: Springer-Verlag.

Bonacci, O., 2004. Poljes. V: Gunn, J. (ur.). Encyclopedia of caves and karst science. New York: Fitzroy Dearborn, str. 599-600.

Cvijić, J., 1895. Karst: geografska monografija. Beograd: Srpska akademija nauka i umetnosti.

Cvijić, J., 1900. Karsna polja zapadne Bosne i Hercegovine (Die Karstpoljen in Westbosnien und in Herzegowina). Glas Srpske kraljevske akademije nauka, 59, 1, str. $59-182$.

Ford, D., Williams, P. D., 2007. Karst hydrogeology and geomorphology. Chichester: Wiley.

Gams, I., 1963. Velo polje in problemi pospešene korozije. Geografski vestnik, 35, 1, str. 55-64. 
Gams, I., 1973. Die zweiphasige quartärzeitliche Flächenbildung in den Poljen und Blindtälern des nordwestlichen Dinarischen Karstes. V: Semmel, A. (ur.). Neue Ergebnisse der Karstforschung in den Tropen und im Mittelmeerraum : Vorträge des Frankfurter Karstsymposiums 1971. Weisbaden: Franz Steiner Verlag, str. 143-149.

Gams, I., 1974. Kras : zgodovinski, naravoslovni in geografski oris. Ljubljana: Slovenska matica.

Gams, I., 1978. The polje: the problem of definition: with special regard to the Dinaric karst. Zeitschrift für Geomorphologie, 22, 2, str. 170-181.

Gams, I., 2003. Kras v Sloveniji v prostoru in času. Ljubljana: Založba ZRC.

Gams, I., Kunaver, J., Radinja, D., 1973. Slovenska kraška terminologija. Ljubljana: Katedra za fizično geografijo, Univerza v Ljubljani.

Gostinčar, P., 2011. Kontaktni kras v Kočevskem Rogu in Kočevski Mali gori. Dela, 35, str. 27-43. DOI: 10.4312/dela.35.27-44.

Gostinčar, P., 2016. Geomorphological characteristics of karst on contact between limestone and dolomite in Slovenia. PhD thesis. Ljubljana: Univerza v Novi Gorici.

Gunn, J. (ur.), 2004. Encyclopedia of Caves and Karst Science. New York, London: Fitzroy Dearborn.

Jennings, J. N., 1985. Karst geomorphology. Oxford: Basil Blackwell.

Jennings, J. N., 1997. Cave and karst terminology. Australian Speleological Federation.

Kunaver, J., 1983. Geomorphology of the Kanin Mountains with special regard to the glaciokarst. Geografski zbornik, 12, 1, str. 201-343.

Mihevc, A., 1991. Morfološke značilnosti ponornega kontaktnega krasa: izbrani primeri s slovenskega krasa. Magistrsko delo. Ljubljana: Univerza v Ljubljani, Filozofska fakulteta.

Mihevc, A., 2010. Geomorphology. V: Mihevc, A., Prelovšek, M., Zupan Hajna, N. (ur.). Introduction to Dinaric karst. Postojna: IZRK ZRC SAZU, str. 30-43.

Mojsisovicz, E., 1880. Zur Geologie der Karst Erscheinungen. Jahrbuch der Geologische Reichsanstalt, 30, 3, str. 1-30.

Nicod, J., 2003. Les karsts dinariques: paysages et problemes : Slovénie, Croatie, Bosnie-Herzégovine, Monténégro. Ljubljana: Slovenian Academy of Science and Arts.

Pavlopoulos, K., Evelpidou, N., Vassilopoulos, A., 2009. Mapping geomorphological environments. Berlin, Heidelberg: Springer.

Roglić, J., 1958. Odnos riječne erozije i krškog procesa. V. kongres geografa FNR Jugoslavije, str. 103-134.

Sauro, U., 2012. Closed depressions in karst areas. V: Culver, W. B., White, D. C. (ur.). Encyclopedia of Caves (Second Edition). Amsterdam: Academic Press, str. 140155.

Smart, C. C., 2004. Glacierized and glaciated karst. V: Gunn, J. (ur.). Encyclopedia of caves and karst science. New York: Fitzroy Dearborn, str. 804-809.

Stepišnik, U., 2014. Japage: the collapse dolines in Kupres Polje, Bosnia and Herzegovina. Dela, 42, 1, str. 5-20. DOI: 10.4312/dela.42.1.5-20. 
Stepišnik, U., 2015. Krasno polje on Velebit Mountain: morphographic and morphogenetic characteristics Hrvatski geografski glasnik, 77, 2, str. 85-99. DOI: 10.21861/ HGG.2015.77.02.05.

Stepišnik, U., 2020. Fizična geografija krasa (v tisku). Ljubljana: Znanstvena založba Filozofske fakultete.

Šušteršič, F., 1986. Model čistega krasa in nasledki v interpretaciji površja. Acta Carsologica, 21, 1, str. 97-116.

White, W. B., 1988. Geomorphology and hydrology of karst terrains. Oxford: Oxford university press.

Williams, P. D., 2004. Karst. V: Goudie, A. S. (ur.). Encyclopedia of geomorphology. London: Routledge, str. 568-594.

Žebre, M., Stepišnik, U., 2014a. Glaciokarst geomorphology of the Northern Dinaric Alps: Snežnik (Slovenia) and Gorski Kotar (Croatia). Journal of Maps, 12, 5, str. 873-881. DOI: 10.1080/17445647.2015.1095133.

Žebre, M., Stepišnik, U., 2014b. Reconstruction of Late Pleistocene glaciers on Mount Lovćen, Montenegro. Quaternary International, 353, str. 225-235. DOI: 10.1016/j. quaint.2014.05.006.

Žebre, M., Stepišnik, U., 2015. Glaciokarst landforms and processes of the southern Dinaric Alps. Earth Surface Processes and Landforms, 40, 11, str. 1493-1505. DOI: 10.1002/esp.3731.

Žebre, M., Stepišnik, U., Colucci, R. R., Forte, E., Monegato, G., 2016. Evolution of a karst polje influenced by glaciation : the Gomance piedmont polje (northern Dinaric Alps). str. 143-154. DOI: 10.1016/j.geomorph.2016.01.005.

Žebre, M., Stepišnik, U., Kodelja, B., 2013. Sledovi pleistocenske poledenitve na Trnovskem gozdu. Dela, 39, str. 157-170. DOI: 10.4312/dela.39.157-170.

\section{KARST POLJES IN SLOVENIA}

\section{Summary}

The article presents a new typification of poljes in karst, which combines the multiple classifications used in contemporary karstologic literature into single one. The presented typification synthesizes morphogenetic and hydrodynamic characteristics of poljes (Gams, 1978; Gams, 2003). It defines them on the basis of the broader geomorphological environments in which they are positioned.

Poljes do not develop in karst environments where solely simple karst processes are operating that are defined by the predominant chemical weathering and the vertical outflow of dissolution into the karst aquifer (Šušteršič, 1986). Poljes are located only within environments where the functioning of the karst is somehow interrupted. Disturbances that condition the formation and functioning of poljes are related to the 
specific hydrogeological characteristics of the karst aquifer or functioning of surface runoff that is causing mechanical transport of sediment over the karst surface.

This type of typification envisages three geomorphic environments of karst (shallow karst, fluviokarst and glaciokarst), which are characterized by four types of poljes: inundated, overflow, inflow and preglacial type. The first two types are the simplest and are related to the shallow karst environments. Local absence of the vadose hydrogeological zone within these karst environments causes permanent or intermittent formation of lakes within karst depressions. Poljes of the inundated type are closed depressions where lake forms without any significant lateral inflow or outflow of surface streams. If the poljes have streams that emerge on one side of polje and flow to the other side where they submerge into subsurface we define them as overflow type of poljes. The formation and functioning of the other two types of poljes are related to the mechanical inflow of material by surface streams from the hinterland into karst depressions. In case of inflow from fluviokarst environments inflow type of poljes develop. If poljes are formed by deposition of streams emerging from glaciers they are defined as proglacial type of poljes.

As part of the research, we typified all 35 poljes of the Slovenian karst. Due to the different types of karst environments, we have classified some poljes into several types. The largest 5 poljes of Slovenia are classified within multiple types. The most diverse are Cerkniško polje and Dobrepolje, which are simultaneously classified as inundated, overflow and inflow types. Other poljes are positioned generally in homogeneous karst environments. Most of the poljes are of inflow type. A smaller number of poljes are within shallow karst environments, among which overflow type predominates. Proglacial type of poljes is typical for glaciokarst environments. These poljes are the rarest in Slovenia. Two of them are located in postglacial environments of the Julian Alps and the Snežnik Mountain.

(Translated by the author) 